$14^{\text {th }}$ Conf. Agric. Develop. Res., Fac. of Agric., Ain Shams Univ., March, 2019, Cairo, Egypt

Special Issue, 27(1), 861 - 868, 2019

Website: http://strategy-plan.asu.edu.eg/AUJASCl/

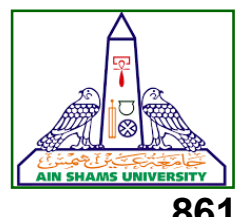

\title{
EFFECT OF DIFFERENT GROUP SIZE ON THE PRODUCTIVE PERFORMANCE OF GROWING RABBITS
}

\author{
Esraa, M.A. Ali ${ }^{1 *}$, El-Wardany I. $^{2}$, Ahmed A.M.H. ${ }^{2}$, Abdel-Kafy E.M. ${ }^{1}$ \\ and Hoda M.A. Shabaan ${ }^{1}$
}

1- Animal Production Research Institute, Agricultural Research Center, Dokki, Gizza, Egypt

2- Poultry Production Dept., Fac. of Agric., Ain Shams Univ., P.O. Box 68, Hadayek Shubra 11241,Cairo, Egypt

*Corresponding author: E_m6645@yahoo.com

Received 24 November, 2018, Accepted 9 December, 2018

\section{ABSTRACT}

This study was carried out to investigate the effect of different group's size on productive performance of growing rabbits. A total number of 108 APRI weaning rabbits, their average initial body weight were $560 \pm 10 \mathrm{~g}$. Animals were assigned to two groups: The $1^{\text {st }}$ group housed by 4 rabbits in cage $60 \mathrm{~cm}^{2}$, while the $2^{\text {nd }}$ group housed by $8 \mathrm{rab}$ bits in cage $120 \mathrm{~cm}^{2}$. During the experimental period live body weight(g), daily feed intake(g) and mortality rate (\%) were recorded and daily body weight gain(g) and feed conversion ratio(FCR) were calculated at $5,8,10$ and 12 weeks of age. After the end of the experiment (12 wk) 36 rabbits were randomly taken and slaughtered to calculate the measure carcass traits. These include total giblet $(\mathrm{g})$, cervix part $(\%)$, front quarters $(\%)$, intermediate part $(\%)$, hind quarter (\%) and the dressing weight. Also the economical efficiency (EE\%) was calculated.

Results indicated that: the average live body weight (LBW), daily weight gain (DWG) and daily feed intake (DFI) were not significantly influenced by different group size. The best DWG values were recorded for the group 2 (8 rabbits/ cage), by around $2.5 \%$ during the whole fatting period (5-12 wks). Daily feed intake was lower in group 2 than group 1 by around $6.20 \%, 2.00 \%, 0.31 \%$ and $2.83 \%$ at $5,8,10$ and 12 weeks of age, respectively. Data revealed significant improvements in FCR for rabbits in group2 $(P<0.05)$ than group1 for the period 5-8 and during the whole growing period 512 weeks. The mortality rate was lower in group 2
\end{abstract}

than in group 1. The best dressing weight value was recorded for the group 2 by around $9.2 \%$. The economical efficiency (EE \%) was improved in group 2. It is concluded that, increasing number of rabbits to 8 rabbits in cage could decrease the mortality $\%$, increase the dressing weight that also lead to increase the economical efficiency.

Keywords: Rabbit, group size, productive performance, economical efficiency.

\section{INTRODUCTION}

Rabbits provide an excellent meat for human consumption and may play a significant role in solving a part of meat shortage in Egypt.

In nature, the home range and group size or size of warren are determined by the risk of predation, the vegetative covering of the area and the quality of the soil. When wild animals such as European wild rabbits in nature choose a habitat (move to another location, decide to live alone, in small or large groups and in several other situations), it appears that they seek to balance benefits and costs.

Many animal species live in groups. One of the most important benefits of group living is the vigilance of flock mates, which is essential in detecting predators in time (Kutsukake, 2009).

It must be borne in mind that benefits and costs on farms differ from those in nature. Artificially reproducing natural conditions may prove disastrous because some of the biggest advantages (e.g., a group living as a defence against predators) are 
not applicable. (Mbanya et al 2004) found that the increase of animals per cage reduces investment costs in cages and equipments, but it worsens animal performance. The European Food and Safety Authority (EFSA) (2005) recommended a minimum surface of $625 \mathrm{~cm}^{2} /$ rabbit and not more than $40 \mathrm{~kg} / \mathrm{m}^{2}$ at the end of fattening, in order to avoid disturbances in rabbit behavior. However, the behavior of rabbits depends on their age. Rabbits at the end of fattening preferred lower densities, and when caged at high densities spent less time for eating (Morisse and Maurice, 1997). Densities higher than $19 \mathrm{rabbit} / \mathrm{m}^{2}$ reduced feed intake and growth rate, with no effect on feed efficiency and mortality (Aubret and Duperray, 1992).

Hoy and Verga (2006) concluded the main welfare indicators for farmed rabbits: no or low mortality, the morbidity should be low or unavoidable, the physiological parameters should be in the species-specific standard and exhibition of species-specific behaviours and the productive performance should be at a normal level.

Therefore, the present work was designed to investigate the effects of group size to APRI on productive performance, carcass traits and economic efficiency.

\section{MATERIALS AND METHODS}

Experiments of the present study were carried out at Sakha Research Station, kafer El-Sheikh Governorate, Animal Production Research Institute (APRI), Agriculture Research Center (ARC), Ministry of Agriculture, Dokki, Giza, Egypt during the period from November 2016 to January 2017.

\section{Experimental Animals}

A total number of 108 APRI rabbits were used in the present study reared from weaning to the end of experiment (from $5 w k$ to $12 w k$ of age). Average initial body weight of individual rabbits was $560 \pm 10 \mathrm{~g}$. Rabbits were randomly divided into two groups in 9 replicate: The first group housed by 4 rabbits in cage $60 \mathrm{~cm}^{2}$ and second group housed by 8 rabbits in cage $120 \mathrm{~cm}^{2}$. Rabbits were kept in tiered cages were equipped with two feeders and nipple for automatic drinking. Animals were healthy and clinically free of external and internal parasites and there were kept under the same managerial and hygienic conditions according to the farm routine work.

\section{Experimental diets}

Experimental diets were formulated to be approximately similar in crude protein (CP) levels and digestible energy (DE), (17\% CP and $2550 \mathrm{kcal} D E$ per per kg diet, Table 1). The diets are formulated to meet the recommendations of the National Research Council for Rabbits (NRC, 1977).

\section{Measurements and observations}

During the experimental period live body weight (g), daily feed intake(g) and mortality rate (\%) were recorded and daily body weight gain $(\mathrm{g})$ and feed conversion ratio ( $\mathrm{FI}$ g/BWG g) were calculated at 5 , 8, 10 and 12 weeks of age. After the end of the experiment all period (12 wk), 36 rabbits (two from each group, four from each replicate) were randomly taken and slaughtered to calculate the economical efficiency (EE\%) and measure carcass traits.

The skin was loosened and peeled from the hocks. A cut was made around the anal opening and between the hind legs, and then the entrails were removed. The giblets (liver, heart, spleen, lungs and kidneys) were separated and weighed. The carcass was weighed after discarding feet, viscera, fur and tail.

The carcass was cut in the following points: cut-point 1 , section between the $7^{\text {th }}$ and $8^{\text {th }}$ thoracic vertebrae; cut-point 2 , section between the last thoracic and the first lumbar vertebra, following the prolongation of the $12^{\text {th }}$ rib when cutting the thoracic wall; cut-point 3 , section between the $6^{\text {th }}$ and $7^{\text {th }}$ lumbar vertebra, cutting the abdominal wall transversally to the vertebral column; cut-point 4 , separation of fore legs including insertion and thoracic muscles according to Blasco et al (1993). The cutpoint 1, FL: Fore-quarter\% (fore legs) including thoracic insertion muscles, cut-point 2, chest $\%$ (thoracic cage which included the first seven ribs, without the insertion muscles of the fore legs); cutpoint 3, lion\% (L) (including abdominal wall and the ribs after the $7^{\text {th }}$ thoracic rib); cut-point 4 , Hind leg\% $(\mathrm{HL})$ (including the sacral bone and the lumbar vertebrate after the 6 th lumbar vertebra). Forequarter\%, Chest $\%$, L\% and $\mathrm{HL} \%$ are percentage of dressing weight. The dressed carcass (saleable carcass) was considered the eviscerated carcass plus the giblets and head. All records were expressed as a relative to live body weight. 
Table 1. Composition and Calculated analysis of the experimental diets

\begin{tabular}{|c|c|}
\hline \multirow[t]{2}{*}{ Ingredients } & $(\mathrm{kg} / 100 \mathrm{~kg})$ \\
\hline & $\mathbf{C}$ \\
\hline Barley & 17.10 \\
\hline Alfalfa hay $12 \%$ & 24.50 \\
\hline Wheat Bran & 25.08 \\
\hline Soybean meal (44\%) & 19.60 \\
\hline Yellow corn & 7.00 \\
\hline Limestone & 1.08 \\
\hline Salt (NaCl) & 0.35 \\
\hline Premix ${ }^{*}$ & 0.30 \\
\hline Molasses & 3.00 \\
\hline Calcium di-Phosphate & 1.71 \\
\hline Anticoccidea & 0.10 \\
\hline Antifungi & 0.10 \\
\hline \multirow[t]{2}{*}{ DL methionine } & 0.08 \\
\hline & Calculated analysis * \\
\hline $\mathrm{DE}(\mathrm{kcal} / \mathrm{kg}$ diet $)$ & 2500 \\
\hline Crude Protein\% & 18.00 \\
\hline Crude Fiber \% & 13.40 \\
\hline Crude Fat \% & 1.90 \\
\hline
\end{tabular}

${ }^{*}$ Premix contains per kilogram : Vit. A 2000000 IU; Vit. D 150000 IU; Vit. E $8.33 \mathrm{~g}$; Vit. K $0.33 \mathrm{~g}$; B1 $0.33 \mathrm{~g}$; Vit. B2 1g; Vit. B6 0.33 g; Vit. B9 8.33 g; Vit. B12 1.7 mg; Pantothenic acid $3.33 \mathrm{~g}$; Biotin $33 \mathrm{mg}$; Folic acid $0.83 \mathrm{~g}$; Choline Chloride $200 \mathrm{~g}$; Zn $11.7 \mathrm{~g}$; Fe $12.5 \mathrm{~g}$; Cu $0.5 \mathrm{~g}$; I 33.3 $\mathrm{mg}$; Se $16.6 \mathrm{mg}$; and Mn $5 \mathrm{~g} .{ }^{* *}$ According to NRC (1994) and According to AOAC (1995).

\section{Economical efficiency (EE)}

The economical efficiency (EE\%) was calculated using the selling price of weight gain and the feeding cost of this gain prevailing in the market, assuming that other costs were constant, (North, 1981).

$E E \%=(($ Selling cost of obtained gain - Feeding cost of this gain) / (Feeding cost of this gain)) $x$ 100.

\section{Statistical analysis}

Data were statistically analyzed using Analysis of Variance procedure using the General Linear
Model Program (GLM) of SAS (1999) using the following model:

$$
Y_{i j k}=\mu_{i}+G_{j}+R_{k}+e_{i j k}
$$

Where:

$$
\begin{aligned}
Y_{i j}= & \begin{array}{l}
\text { The observed value of } a \\
\text { given dependent variable }
\end{array} \\
\mu_{i}= & \text { Overall adjusted mean } \\
& \text { Effect of studied factor } j^{\text {th }} \\
G_{j}= & \text { due to group, } j=1 \text { and } 2 \\
& \text { Replicate of treatment } k^{\text {th }} \\
R_{k}= & \text { due to replicate, } k=1 \text { to } 9 \\
e_{i j}= & \text { Error of the model }
\end{aligned}
$$

The differences among means were tested using Duncan's multiple range test (Duncan, 1955).

\section{RESULTS AND DISCUSSION}

\section{Growth performance}

\section{Live body weight and body weight gain}

The effect of group on performance during the growing period (5-12 weeks of age) is shown in Table 2. In general, there were no significant differences in LBW, DWG and DFI among rabbit groups at different experimental periods.

Although, the results showed that DWG was not significantly changed with different group size, but the best DWG values were recorded for the group 2 (8 rabbits/ cage), by around $2.5 \%$ during the whole fatting period (5-12 wks).

The results are in close agreement with many authors who reported non-significant effect in LBW and DWG of growing rabbit by using different group size. The slow growth rate can be related to high locomotory activity because part of the ingested energy is used for this purpose (Princz et al 2009 and Szendrő and Dalle Zotte, 2011)).

On the other hand, these results are different than what has been observed by (Maertens and Van Herck, 2000; Lambertini et al 2001; Maertens and Van Oeckel, 2001; Dal Bosco et al 2002 and Jehl et al 2003) who showed that different size group was significantly affected on some productive traits like the decline in daily weight gain and the reduction was between 1.0 and 9.3 $\mathrm{g} /$ day and also different than what has been reported by many authors with (Combes et al 2010 and Khairy et al 2018) who found that final weight has been significantly reducted between 33 and $445 \mathrm{~g}$. 


\section{Daily feed intake and feed conversion ratio}

Daily feed intake of rabbits as influenced by different group size and growing period are presented in Table (2). It appears from these results that DFI was non-significantly affected by different group size. This effect was lower in group 2 (8 rabbits/ cage) than group 1 (4 rabbits/ cage) by around $6.20 \%, 2.00 \%, 0.31 \%$ and $3.83 \%$, respectively. However; the lowest DFI values were recorded for rabbits in group 2 during the whole period (5-12 wks).

This results are in close agreement with those obtained by Szendrő and Dalle Zotte (2011) and Khairy et al (2018) and, in some cases, the differences (5-25g/day) were significant (Maerens and Van Herck, 2000; Dal Bosco et al 2000; Maertens and Van Oeckel, 2001 and Lambertini et al 2001). Theoretically, when animal energy requirements increase because their movement increases, they consume more feed (Lambertini et al 2001; Szendrő and Dalle Zotte 2011). However, some studies have shown an opposite trend (Dal Bosco et al 2002 and Princz et al 2009)

Maertens and Van Herck (2000) observed that during the first days after weaning, kits in pens were very sensitive towards visitors, noise and handling. They ran together and heaped up in a corner of the pen and tried to escape. The authors concluded that housing rabbits in larger groups (larger pens) induces stress for them. This could explain why kits reared in larger groups consumed less feed than those in smaller groups.

Concerning the effect of different group size on FCR data revealed significant improvements in FCR for rabbits in group $2(\mathrm{P}<0.05)$ than group1 for the period 5-8 and during the whole growing period 5-12 weeks. This was probably due to the effect of the high size content of cage (Szendrö and Dalle Zotte, 2011 and Khairy et al 2018)

Feed conversion ratio in groups of three to four or six to seven rabbits per cage improved by 0.05 0.20 , as compared with individual or bicellular housing (Szendrő et al 2009). When group size exceeded seven rabbits per cage, FCR worsened by $0.20-0.50$ (Lambertini et al 2001; Dal Bosco et al 2002 and Princz et al 2009).

\section{Mortality rate}

The effect of different group size on mortality rate is illustrated in Fig. (1). It is clear from these results that the mortality rate was lower in group 2 (8 rabbits/ cage) than in group 1 (4 rabbits/ cage) by $5.71 \%$.

In most cases, mortality has been observed to be independent of group size (Maertens and Van Herck, 2000; Maertens and Van Oeckel, 2001; Princz et al 2009 and Szendrő et al 2009) and Dal Bosco et al (2002) using two or 10 rabbits per cage and Lang (2009) with 8-22 rabbits per cage detected significant increases in mortality in larger groups. The main reason for this lack of correlation between group size and mortality could be attributed to the common practice of providing medication in the feed (Szendrő and Dalle Zotte 2011).

\section{Carcass traits}

Carcass traits of rabbits as influenced by different group size are presented in Table (3). It appears from these results that carcass traits were non-significant affected by different group size. However; total giblet $(\mathrm{g})$, front quarters (\%) and intermediate part (\%) were increase in large group by $13.20,14.92$ and 0.86 , respectively. That is may be related to greater locomotory activity resulting in an increase in the muscle size as reported by Szendrö and Dalle Zotte (2011).

However; Szendrö and Dalle Zotte (2011) reported that a tendency towards a decrease in the ratio of fore part to the reference carcass (0.2$0.6 \%$ ) was observed.

There was no definite change in the intermediate part, while the hind part of animals housed in larger groups increased by $0.1-1.7 \%$ as reported by Dal Bosco et al 2002; Dalle Zotte et al 2009; Szendrő et al 2009; Combes et al 2010. The increase in the hind part is related to greater locomotory activity resulting in an increase in the muscle size. Dal Bosco et al (2002), Szendrő et al (2009) and Combes et al (2010) found that the fat deposits decreased with increasing group size. On the other hand, Khairy et al 2018 found that low group size had a significant effect on hot carcass weight and dressing out percentage. 
Table 2. Effect of using different size groups on productive performance of growing APRI rabbits during different experimental periods

\begin{tabular}{|c|c|c|}
\hline \multirow{2}{*}{ Items } & \multicolumn{2}{|c|}{ Groups } \\
\hline & G1 & G2 \\
\hline Live body weight (q): & & \\
\hline Weaning 5 weeks & $559.39 \pm 16.20$ & $540.93 \pm 11.45$ \\
\hline 8 weeks & $882.31 \pm 26.43$ & $886.76 \pm 18.69$ \\
\hline 10 weeks & $1118.17 \pm 34.36$ & $1127.78 \pm 24.30$ \\
\hline 12 weeks & $1369.93 \pm 44.73$ & $1365.14 \pm 30.15$ \\
\hline daily weight gain $(g):$ & & \\
\hline 5-8 weeks & $15.38 \pm 0.91$ & $16.47 \pm 0.64$ \\
\hline 8-10 weeks & $16.85 \pm 1.02$ & $17.22 \pm 0.72$ \\
\hline $10-12$ weeks & $17.98 \pm 1.20$ & $16.95 \pm 0.81$ \\
\hline $\begin{array}{l}\text { 5-12 weeks } \\
\text { daily feed intake }(g) \text { : }\end{array}$ & $16.54 \pm 0.78$ & $16.82 \pm 0.53$ \\
\hline$\overline{5-8 \text { weeks }}$ & $54.64 \pm 2.64$ & $51.25 \pm 2.64$ \\
\hline 8-10 weeks & $78.73 \pm 4.04$ & $77.19 \pm 4.04$ \\
\hline $10-12$ weeks & $81.73 \pm 6.98$ & $81.48 \pm 6.98$ \\
\hline $\begin{array}{l}\text { 5-12 weeks } \\
\text { daily feed conversion ratio (FI/WG): }\end{array}$ & $69.26 \pm 2.84$ & $67.30 \pm 2.84$ \\
\hline $5-8$ weeks & $3.55^{\mathrm{a}} \pm 0.15$ & $3.13^{b} \pm 0.15$ \\
\hline 8-10 weeks & $4.67 \pm 0.19$ & $4.45 \pm 0.19$ \\
\hline 10-12 weeks & $4.55 \pm 0.12$ & $5.14 \pm 0.12$ \\
\hline 5-12 weeks & $4.10^{\mathrm{a}} \pm 0.18$ & $4.00^{b} \pm 0.18$ \\
\hline
\end{tabular}

${ }_{a, b}$ Mean with different superscripts in the same row within item differ significantly $(P<0.05)$.

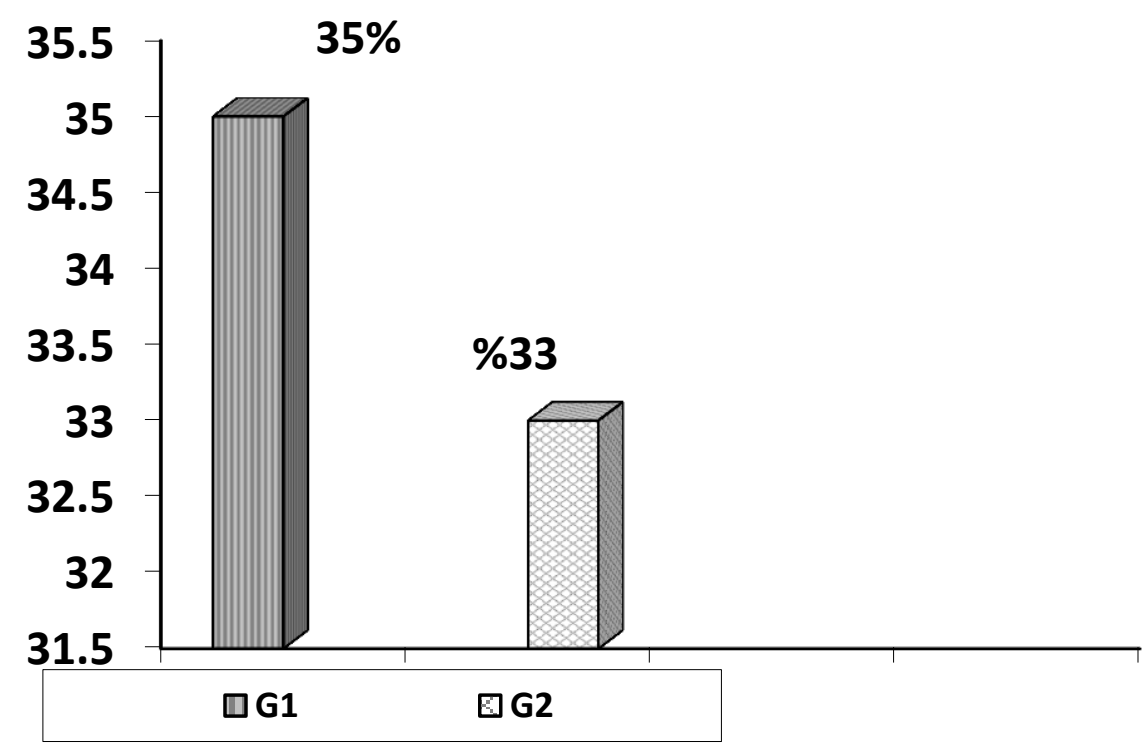

Fig. 1. Effect of using different size groups on total mortality rate of growing APRI rabbits by the end of experimental periods. 
Table 3. Effect of using different size groups on carcass traits of growing APRI rabbits at 12 weeks of age

\begin{tabular}{|l|c|c|c|}
\hline \multirow{2}{*}{\multicolumn{1}{|c|}{ Items }} & \multicolumn{2}{c|}{ Group } & \multirow{2}{*}{ E SE } \\
\cline { 2 - 3 } & G1 & G2 & \\
\hline Pre-slaughter (g) & 1336.94 & 1493.61 & 60.55 \\
Total giblet (g) & 160.25 & 181.40 & 8.35 \\
Cervix part (\%) & 11.59 & 11.07 & 0.32 \\
Front quarters (\%) & 5.66 & 6.50 & 0.67 \\
Intermediate part (\%) & 7.68 & 7.74 & 0.71 \\
Hind quarter (\%) & 16.69 & 16.69 & 0.37 \\
Dressing weight & 727.19 & 800.96 & 41.31 \\
\hline
\end{tabular}

The economical efficiency (EE \%)

The effect of different group size on the economical efficiency (EE \%) of rabbit are illustrated in Table (4). It is clear from these results that the economical efficiency (EE \%) was increase in group 2 by $11.07 \%$. It could be more economic than size under farm conditions. The main reason for this best of correlation between group size and the economical efficiency could be attributed to the common practice of providing medication in the feed and the decrease in mortality, Amber (2018) found that the economical efficiency was decreased from 1.17 to $0.96 \%$ as the number of rabbits increased from 2 to 6 per cage.

Table 4. Effect of using different size groups on Input-output analysis and economical efficiency of growing APRI rabbits

\begin{tabular}{|c|c|c|}
\hline Items & G1 & G2 \\
\hline Total feed intake diet & 4.37 & 4.02 \\
(kg/rabbit) & 13.83 & 12.70 \\
Total feed cost (L.E.) & 1.37 & 1.36 \\
Average weight gain $_{(\mathbf{k g} / \text { rabbit) }}$ & 43.84 & 43.63 \\
Selling price (L.E.) $^{(\mathbf{1})}$ & 30.01 & 30.93 \\
Net revenue (L.E.) $^{(\mathbf{2})}$ & 2.17 & 2.44 \\
\hline Economical efficiency $^{(\mathbf{3})}$ &
\end{tabular}

(1) Price of $\mathrm{kg}$ live body weight was 32 L.E. Commercial diet price (L.E./ton) at 2016 were:2800

(2) Net revenue = Selling price-total feed cost

(3) Economic efficiency $=$ Net revenue/total feed cost

\section{REFERENCES}

Amber Kh., Eid Y.Z., Azoz A.A. and El-Gebaly M.M. 2018. Effect of Stocking Density and Dietary Phytobiotics on Growth Performance in Rabbit During Summer Season. J. Sus. Agric. Sci., 44(1), 13 -20.

AOAC 1995. Association of Official Analytical Chemists. Official Methods of Analyses. $16^{\text {th }}$ Ed., Washington, DC, USA.

Aubret J.M. and Duperray J. 1992. Effect of cage density on the performance and health of the growing rabbit. J. Appl. Rabbit Res., 15, 656660.

Blasco A., Ouhayoun J. and Masoero G. 1993. Harmonization of criteria and terminology in rabbit meat research. World Rabbit Sci., 1, 310.

Combes S., Postollec G., Cauquil L., Gidenne T., Combes S., Postollec G., Cauquil L. and Gidenne T. 2010. Influence of cage or pen housing on carcass traits and meat quality of rabbit. Animal. 4(2), 295-302.

Dal Bosco A., Castellini C. and Mugnai C. 2002. Rearing rabbits on a wire net floor or straw litter: behaviour, growth and meat qualitative traits. Livestock Production Sci., 75, 149156.

Dal Bosco A., Castellini C. and Bernardini M. 2000. Productive performance and carcass and meat characteristics of cage- or pen-raised rabbits. World Rabbit Sci. 8, Suppl. A, 579583.

Dalle Zotte A., Princz Z., Metzger Sz., Szabó A., Radnai I., Biró-Németh E., Orova Z. and Szendrő Zs. 2009. Response of fattening rabbits reared under different housing conditions. 2. Carcass and meat quality. Livest. Sci., 122, $39-47$.

Duncan D.B. 1955. Multiple ranges and multiple Ftest. Biometrics, 11, 1-42.

EFSA 2005. Opinion on the "Aspects of the biology and welfare of animals used for experimental and other scientific purposes", The European Food and Safety Authority. The EFSA J. 292, 1- 46.

Hoy St. and Verga M. 2006. Welfare indicators. In: Maertens, L., Coudert, P. (eds.), ILVO, Melle, Belgium, Rabbit Sci. pp. 71-74. 
JehI N., Meplain E., Mirabito L. and Combes S. 2003. Incidence de trois modes logement sur les performances zootechniques et la qualité de la viande de lapin. Proc. 10émes Journ. Rech. Cunicole, Paris, France, pp. 181-184.

Khairy M. El-Bayoumi, Mahmoud S. ElTarabany, Tamer M. Abdel-Hamid and Wafaa R.I.A. Sherief 2018. Effect of Stocking Density on Growth Performance, Carcass Traits and Some Hematological Parameters of New Zealand White Rabbits. Global Veterinaria, 20(1), 1-5.

Kutsukake N. 2009. Complexity, dynamics and diversity of sociality in group-living mammals. Ecol. Res. 24, 521-531.

Lambertini L., Vignola G. and Zagnini G. 2001. Alternative pen housing system for fattening rabbits: Effect of density and litter. World Rabbit Sci. 9, 141-147.

Lang C. 2009. Klinische und etologische Untersuchangen zur Haltung wachsender Kaninchen. Diss. Univ., Giessen, Germany, (Cited by Szendrő Zs. and Dalla Zotte A. 2011).

Maertens L. and Van Oeckel M.J. 2001. Effect du logement en cage on en parc et de son enrichment sur les performances et la couleur de la viande des lapins. Proc. 9émes Journ. Rech. Cunicole, Paris, France, pp. 31-34.

Maertens L. and Van Herck A. 2000. Performance of weaned rabbits raised in pens or in classical cages: First results. World Rabbit Sci. 8, 435-440.

Mbanya J.N., Ndoping B.N., Fomunyam R.T., Noumbissi A., Mbomi, E.S., Fai E.N. and
Teguia A. 2004. The effect of stocking density and feeder types on the performance of growing rabbits under conditions prevailing in Cameroon. World Rabbi Sci., 12, 259-268.

Morisse M. and Maurice R. 1997. Influence of stocking density or group size on behaviour of fattening rabbits kept under intensive conditions. Appl. Anim. Behav. Sci., 54, 351-357.

North M.O. 1981. Commercial Chicken. Production Manual. $2^{\text {nd }}$ Ed. AVI publishing Co. INC., Westpost Connicticut, USA. 710 p.

NRC. 1977. Nutrient Requirements of Rabbits National Research Council, $2^{\text {nd }}$ Ed. Nat. Acad. Sci. Washington, DC.USA.

Princz Z., Dalle Zotte A., Metzger Sz., Radnai I., Biró-Németh E., Orova Z. and Szendrő Zs., 2009. Response of fattening rabbits reared under different housing conditions. 1. Live performance and health status. Livest. Sci., 121, 86-91.

SAS. 1999. SAS Users guide: statistics.Analysis system. Institute, Inc., Cary, N.C.

Szendrő Zs. and Dalla Zotte A. 2011. Effect of housing conditions on production and behaviour of growing meat rabbits: A Review. Livestock Sci., 137, 296-303.

Szendrő Zs., Matics Zs., Nagy I., Odermatt M., Gerencsér Zs., Szendrő É., Radnai I. and Dalle Zotte A. 2009. Examination of growing rabbits housed in pens without or with platform. $16^{\text {th }}$ International Symposium on housing and diseases of rabbits, Furbearing Animals and Pet Animals, Celle, Germany, pp. 3-12. 

المؤتمر الرابع عشر لبحوث التنتمية الزراعية،

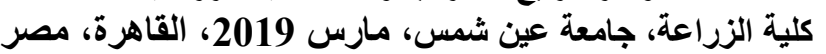

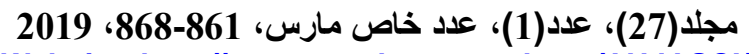

868 Website: http://strategy-plan.asu.edu.eg/AUJASCI/

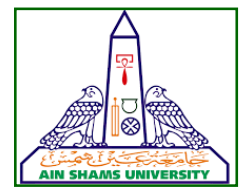

تأثير حجم المجموعات المختلفة على الآداء الإنتاجى للأرانب النامية

[78]

\author{
إسراء محمد عبدالمجيد على 1- إبراهيم الوردانى السيد²- أيمن محمد حسن أحمد2 -

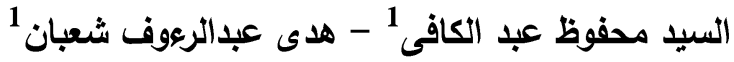

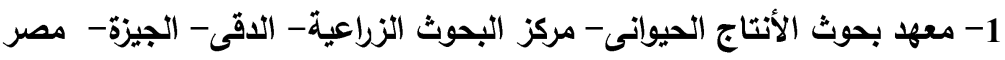 \\ 2- قسم انتاج الدواجن - كلية الزراعة - جامعة عين شمس - ص.ب 68- حدائق شبرا 11241 - القاهرة - مصر الأبر
}

*Corresponding author: E_m6645@yahoo.com

Received 24 November, 2018, Accepted 9 December, 2018

لوحظ ان الزيادة اليومية فى وزن الجسم للمجموعة

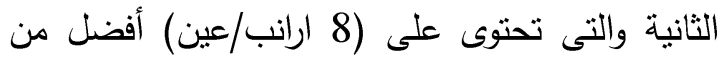

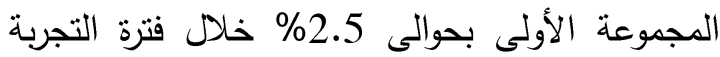
(12-5 أسبوع). لم تتأثر كمية الغذاء المأكول بحجم

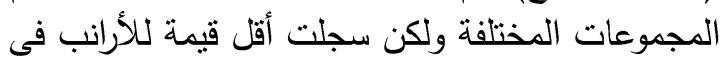

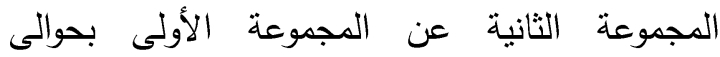

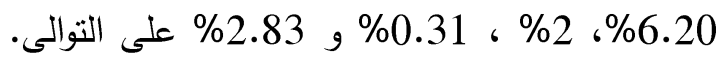
كان هنالك تحسن معنوى فى كفاءة التحويل الغذائى

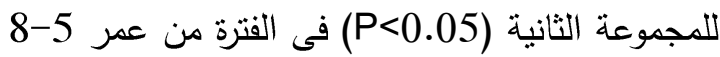
أسابيع وأثناء الفترة من عمر 5-12-12 أسبوع. كان لإستخدام مجموعات مختلفة تأثير على معدل النفوق حيث كان معدل النفوق فى المجموعة الثانية له تأثنير

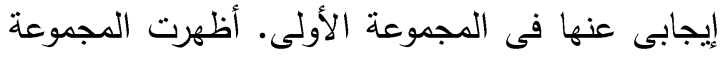
الثانية زيادة فى الكفاءة الأقتصادية عن الأولى المجموعة المجوعة

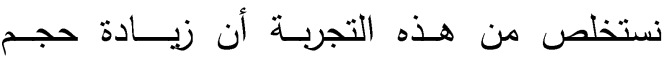
الأولى.

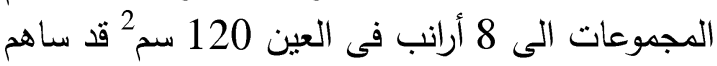
فى إنخفاض معدل النفوق وزيادة نسبة التصافى فى التى

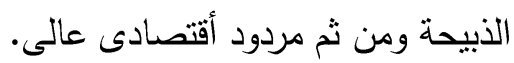
الكلمات الدالة: أرنب، حجم المجموعات، الآداء الانتاجى، الكفاءة الاقتصادية الأب،

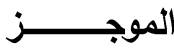

أجريت هذه الدراسة لمعرفة تأثير حجم المجموعات المختلفة على الآداء الإنتاجى للأرانب النامية.استخدم الندام

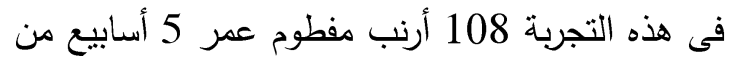
سلالة الأبرى بمتوسط وزن النجرية 560+108جرام / أرنب.

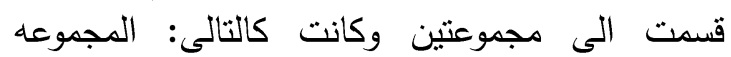
الأولى تحتوى على 4 أرانب تم اسكانهم فى مساحة

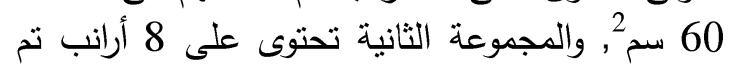

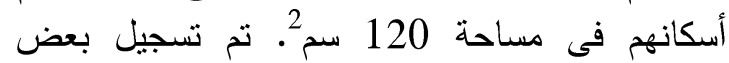
النتائج مثل وزن الجسم،الزيادة فى وزن الجسم، كمية الغذاء المأكول، كفاءة التحويل الغذائى وذللك على عمر التى

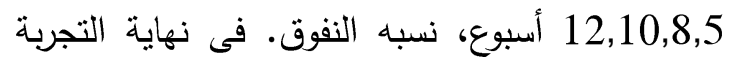

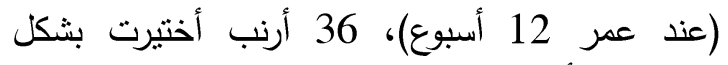
عشوائى 2 أرنب من كل مجموعة وذبحت لتقدير بعض أنبرت صفات الذبيحة والقطعيات. و كذاللك تم تقدير الكفاءة الإقتصادية.

$$
\text { أظهرث النتائج التالى }
$$

لم يتسبب اسخدام اعداد مختلفة فى المجموعات فى المى

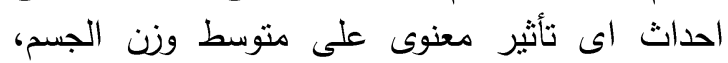
الزيادة اليوميه فى وزن الجسم و المأكول اليومى، بينما معنى لجئ 